Jurnal Cahaya Mandalika, Vol. 2, No. 2, Juli 2021 ,e- ISSN: 2721-4796

Available online at: ojs.cahayamandalika.com/index.php/jcm

Copyright @ 2021 Published by: Institut Penelitian \& Pengembangan Mandalika Indonesia

\title{
DETERMINANTS OF SUSTAINABLE HEALTH DEVELOPMENT
}

\author{
Sri Sulistiowati ${ }^{1}$ and I Gusti Wayan Murjana Yasa $^{2}$ \\ Faculty of Economics and Business, Udayana University, Denpasar Bali \\ Email: ${ }^{1}$ srisulistiowati01@gmail.com
}

\begin{abstract}
Sustainable health development is a change that leads to a positive or better in the social, economic aspects whose implementation does not ignore the ecological or environmental and social aspects where all levels of society depend on environmental aspects. The successful implementation of sustainable health development requires integrated policies, planning and social learning processes. One of the government's efforts to encourage hospitals to prioritize service, safety and protection for the community is to require hospitals to carry out accreditation. Accreditation is an acknowledgment given to hospitals because they have strived to improve the quality of services on an ongoing basis. To ensure the realization of sustainable health development, it is very dependent on social capital, especially the community's ability to manage and overcome economic, social and environmental pressures. Communities that are endowed with wealth of social capital are in an advantageous position in implementing development programs. Thus, a healthy society will always be in a prosperous state, because it is still able to live productively. According to the previous explanation, it is known that government policies, social capital and public welfare affect the health of the community in a sustainable manner. This study tries to formulate the problem (1) How is the relationship between government policy and sustainable health development?; (2) What is the relationship between social capital and sustainable health development and (3) What is the relationship between welfare and sustainable health development?. This research is a literature review related to government policies in the health sector. Through the literature, this study attempts to analyze the relationship between government policy, social capital and welfare in relation to sustainable health. The conclusions of this study are (1) government policies affect sustainable health development?; (2) social capital affects sustainable health development and (3) welfare affects sustainable health development?
\end{abstract}

Keyword: Sustainable; Health; Development.

\section{INTRODUCTION}

Health is a basic right for the community to obtain health services, in this case it is the obligation of the government, both central and local to make it happen. Affordable and quality health services are the dream of all levels of society, especially for the lower middle class. In fact, health institutions or institutions have not been able to provide the health services expected by the community. Health costs are getting more expensive, but the quality of the services provided is a lot of complaints from the community.

Health according to the Law of the Republic of Indonesia Number 36 of 2009 is healthy health, both physically, mentally, spiritually and socially that allows everyone to live socially and economically productive. The health sector is an important part of the economy in many countries. Without health, the wheels of the economy in a country will not be able to turn and run in an effort to drive national development. As happened in early 2020 until now where the world has been affected by the Corona Virus Disease (COVID-19) outbreak. This epidemic has paralyzed the economy in almost all countries around the world. Many economists have stated that this year there will be a global recession due to the COVID-19 pandemic, this means that various developments that have been prepared by each country will not be carried out.

In an effort to create good health policies, it is the biggest challenge for the leaders who work in each public hospital in each region. There are previous studies that highlight the characteristics of health institutions with superior and resilient systems such as that conducted by Erwin et.al., (2014), the study tries to identify factors that can be modified in order to protect health institutions from mistakes in the process of implementing health policies. . Thus, there is an obligation for hospitals to accredit the services provided. In addition, the government has also required local governments to support hospitals in their regions to carry out accreditation related to their health services. 
The polemic in health policy is related to problems in the health care system that often arise, namely cases of patient refusal. Furthermore, in the implementation in the field, the health services provided by the hospital are still problematic. Patients have to look for rooms from one hospital to another because they are fully informed by the hospital (Gunawan et.al., 2015).

One of the government's efforts to encourage hospitals to prioritize service, safety and protection for the community is to require hospitals to carry out accreditation. According to Permenkes No. 12 of 2012, accreditation is an acknowledgment given to hospitals because they have made efforts to improve the quality of services on an ongoing basis. This recognition is given by an independent institution in charge of accreditation and has obtained recognition from the Minister of Health. The independent institution in charge of accrediting hospitals in Indonesia is the Hospital Accreditation Commission (KARS).

One of the government's efforts to encourage hospitals to prioritize service, safety and protection for the community is to require hospitals to carry out accreditation. Accreditation is an acknowledgment given to hospitals because they have strived to improve the quality of services on an ongoing basis.

To ensure the realization of sustainable health development, it is very dependent on social capital, especially the community's ability to manage and overcome economic, social and environmental pressures. Communities that are endowed with wealth of social capital are in an advantageous position in implementing development programs. Thus, a healthy society will always be in a prosperous state, because it is still able to live productively.

From the explanation of several phenomena that become the main problems in the implementation of health policy, this research tries to formulate the problem (1) What is the relationship between government policy and sustainable health development?; (2) What is the relationship between social capital and sustainable health development and (3) What is the relationship between welfare and sustainable health development?

\section{LITERATURE REVIEW Public health}

In studying public health, it is necessary to understand the related meanings, namely Health and Society. Health according to the Law of the Republic of Indonesia Number 36 of 2009 is healthy health, both physically, mentally, spiritually and socially that allows everyone to live socially and economically productive. The definition of society is the unity of human life that interacts according to a certain system of customs that is continuous, and which is bound by a sense of shared identity.

Notoatmodjo (2003) mentions efforts in public health such as improving environmental sanitation, eradicating infectious diseases, education for personal hygiene, organizing medical and nursing services for early diagnosis and treatment, and developing social engineering to ensure that everyone's needs are met. a decent life in maintaining their health. Public health refers to all organized actions (whether public or private) to prevent disease, promote health, and prolong life among the population as a whole, whose activities aim to provide conditions in which people can be healthy and focus on the whole population and have a close relationship with the health system as a whole. 
Jurnal Cahaya Mandalika, Vol. 2, No. 2, Juli 2021 ,e- ISSN: 2721-4796

Available online at: ojs.cahayamandalika.com/index.php/jcm

Copyright (c) 2021 Published by: Institut Penelitian \& Pengembangan Mandalika Indonesia

\section{Sustainable Health Development}

The health system is needed in health development, this health system will work to increase life expectancy, decrease disease burden and improve attitudes and behavior, as well as fulfill community satisfaction with health services. As stated in the Strategic Review of Health and Medical Research, this health system consists of resources (money spent by the community, either directly or indirectly through health funds or taxes), unit costs of people (health personnel costs and health facility costs). , productivity (clinical services per person), and effectiveness (health outcomes per clinical service) (McKeon, 2013).

The health system in Indonesia when compared to neighboring countries such as Singapore and Malaysia is still very lagging, of course this illustrates the relatively low life expectancy of GDP, where health care costs are projected to grow at an unsustainable rate. Health care research has an important role in identifying opportunities and strategies to improve the efficiency of healthcare services and ensure the sustainability of the health system as a whole (McKeon, 2013).

\section{Government Policy in the Health Sector}

Understanding the relationship between health policy and health itself has become so important that it is possible to address the major current health problems (such as rising obesity, the HIV/AIDS epidemic, increasing drug resistance) while understanding how the economy and other policies impact health. Health policy provides direction in selecting health technologies to be developed and used, managing and financing health services, or the types of drugs that can be purchased over the counter. To understand this, it is necessary to define what is meant by health policy.

Since the beginning, the government has made various policies to improve infrastructure in all public hospitals in Indonesia. Gradually, one by one government policies were introduced in order to improve health facilities, invest in modern medical equipment, and develop the most advanced specialties. The government has made an ambitious development and expansion of the health system to encourage community participation and initiatives in providing health services for the elderly, chronic diseases, severe illnesses, and mental illnesses, the government began to provide subsidies to the community and continues to this day (Haseltine, 2013 ).

\section{Social Capital}

Social capital is needed to create the kind of moral community that cannot be obtained as in the case of other forms of human capital. The acquisition of social capital requires getting used to the moral norms of a community and in its context simultaneously adopting virtues such as loyalty, honesty, and dependability (Fukuyama, 1995). Social capital is the features of social life - networks, norms and beliefs that enable participants to act together more effectively in achieving common goals (Putnam, 1996).

Social capital is very important for the community, because it provides easy access to information for community members, becomes a medium for sharing power in the community, develops solidarity, enables the mobilization of community resources, allows for shared achievements, and forms community behavior and community organization as stated by Lesser (2000).

Approaches to social capital in general can be done through two perspectives, as stated by Rosyadi (in Yustika, 2012). First, it examines social capital from the actor's perspective formulated by Bourdieu, who sees social capital as containing resources that individual actors can use because of their ownership of the network exclusively (exclusive 
networks). Second, looking at social capital from a society's perspective conceptualized by Putnam, who sees capital as a public good that is governed by horizontal organizations and networks that exist in society..

To ensure the realization of sustainable health development, it is very dependent on social capital, especially the ability of the community to manage and overcome economic, social and environmental pressures. Communities that are endowed with wealth of social capital are in an advantageous position in implementing development programs. Thus, a healthy society will always be in a prosperous state, because it is still able to live productively.

\section{Public Welfare}

Everyone has a desire for prosperity, which is a state of well-being or a condition in which people are prosperous, healthy, and peaceful. The income earned must be used for important consumption, so that it can provide benefits for their lives. Mankiw (2007) describes welfare as a condition in which basic human needs have been fulfilled in accordance with human quality standards of life such as clothing, health, housing, education, income, social or spiritual benefits.

Furthermore, Stiglitz et.al., (2011) divide welfare into several dimensions which include material living standards (income, consumption and wealth), health, education, individual activities including work, political voice and governance, social relations and kinship, the environment. life (present and future conditions), insecurity both economic and physical. All of these dimensions indicate the quality of life of the community and to measure it, objective and subjective data are needed. Improving the quality of human life shows an increase in welfare (Bronsteen et.al., 2009).

Life satisfaction as part of the welfare dimension includes health, acceptance of economic adequacy, assistance (social support), and social interaction. According to Sugiharto (2007) there are eight indicators used to determine the level of welfare, namely income, family consumption or expenditure, living conditions, housing facilities, health of family members, ease of obtaining health services, ease of enrolling children in education, and ease of access to education. transportation facilities. Meanwhile, the indicators used to measure the level of welfare are according to the criteria made by the Central Statistics Agency (BPS), namely income levels, health levels, and education levels so as to increase the Human Development Index (IPM) of the community.

\section{RESEARCH METHOD}

This research is a literature review related to government policy, social capital and welfare with sustainable health. Through literature, this paper attempts to analyze the relationship between government policy, social capital and welfare on sustainable health development.

\section{DISCUSSION}

\section{Relationship between Government Policy and Sustainable Health Development}

Health is affected by a number of decisions that have nothing to do with health services, where poverty affects public health, as does pollution, dirty water or poor sanitation. Economic policies, such as taxes on smoking or alcohol can also influence people's behavior. Recent causes of increasing obesity in the community include the availability of cheap but high-calorie fast food, the sale of soft drinks in schools, as well as decreased exercise habits. 
In order to achieve optimal health in a population, a good combination is needed to prevent ill health and respond to cases of disease with curative services. Both are important, but there are predictable obstacles to achieving a balance. Too often we are faced with only one limited government health budget, and this is all that is available for investment in public health services. Various factors have influenced this public health budget allocation, ideally these factors include efficiency and equity. In reality, concerns also include policy and political priorities, which often take precedence over efficiency and equity criteria.

Social factors exert a combined effect on the health of individuals and populations. The most important thing to do is long-term change in the social environment, which is a joint effort of various government and non-government sectors. However, linking policy efforts with public health practice at different levels of governance remains a challenge. Study after study has shown that these health-related realities of everyday life are tied to policy. Structural factors that determine public health such as income, education, employment, access to resources, living and working conditions, policies and governance, all of which can determine the position of public health. Leonard Syme, a Professor Emeritus of Epidemiology at the University of California, argues that public health interventions can be well designed and implemented well, through strong public policies and by empowering people to act.

There are often obstacles to incorporating research results into policy, such as limited budgets, which are systemic and not easily changed. However, some of the barriers to health policy making have been overcome and implemented well based on evidence from findings in previous studies. Policymakers can benefit from evidencebased health skills training to help them identify and evaluate high-quality information. Thus, researchers and policy makers can collaborate to develop networks in order to produce relevant health policies for improving public health in order to build sustainable health.

\section{Relationship of Social Capital with Sustainable Health Development}

Coleman (1998) mentions that there are at least three forms of social capital. First, the structure of obligations (obligations), expectations (expectations), and trust (trustworthiness). In this context, Yustika (2012) suggests that the form of social capital is highly dependent on two key elements, namely: trust from the social environment, and the actual expansion of obligations that have been fulfilled (obligation held). Social capital has a positive contribution in relation to employee commitment, organizational flexibility, better management of collective action, and the development of knowledge capital (conceptual capital).

Social Capital indicators are very broad in scope. In this study, collaborating indicators of social capital proposed by Hasbullah (2006) who called it the main elements of social capital. Furthermore, it is said that the study of social capital lies in how the ability of the community in a group entity to participate in building a network to achieve common goals. This cooperation is characterized by a pattern of mutually beneficial interactions, and is built on trust which is supported by positive and strong social norms and values. Meanwhile, Ridell in Wimba (2015), said that there are three parameters of social capital, namely: network, trust, and norms.

Social capital is very important for the community, because it provides easy access to information for community members, becomes a medium for sharing power in the community, develops solidarity, enables the mobilization of community resources, allows 
Jurnal Cahaya Mandalika, Vol. 2, No. 2, Juli 2021 ,e- ISSN: 2721-4796

Available online at: ojs.cahayamandalika.com/index.php/jcm

Copyright (c) 2021 Published by: Institut Penelitian \& Pengembangan Mandalika Indonesia

for shared achievements, and forms community behavior and community organization as stated by Lesser (2000). ).

Social capital indirectly has an impact on population productivity and economic sustainability, as well as regional social sustainability, because it affects the number of available workers either through proximity and kinship or social relations so that it affects employment opportunities and incomes of the population. Social capital also indirectly affects the number of people available to find work, either through closeness and kinship or social relations. Social capital in groups can affect the stability of family life and community independence so as to increase productivity and income.

To ensure the realization of sustainable development, it is very dependent on social capital, especially the ability of the community to manage and overcome economic, social and environmental pressures. Communities endowed with a wealth of social capital, including social networks, norms and values related to social relations, are in an advantageous position in resolving disputes, sharing information, and successfully implementing development programs. However, the success of program implementation cannot be equated between one community and another, even with the availability of the same production factors, because they have different social capital.

\section{Welfare Relationship with Sustainable Health Development}

The COVID-19 phenomenon has changed the world's perspective, where health is the most important variable in the process of achieving the welfare objective of a nation. Therefore, health is considered as the main capital and has the most positive rate of return for both individuals and society. In a situation like this, it is necessary to conduct a more indepth study related to Health Economics, where there is a relationship between health and the economy (Trisnantoro, 2004). Health affects economic conditions, and vice versa the economy affects health. A better health condition will increase productivity, increase per capita income, increase the country's economic growth.

In the context of realizing social welfare, development in various sectors must continue and be pursued, as well as in various conditions and situations. Likewise, in the situation of the COVID-19 pandemic, where social welfare must continue to be realized, it is not only the state that can do it, but efforts from the community are also needed. Synergy from both parties will be better and can accelerate the recovery of a country's condition to normal again, so that the impact of the COVID-19 pandemic can be suppressed as low as possible so that it does not cause significant effects in life. Of course, these efforts require strong social capital in the community.

Health is a basic right for the community to obtain health services, in this case it is the obligation of the government, both central and local to make it happen. Affordable and quality health services are the dream of all levels of society, especially for the lower middle class. In fact, health institutions or institutions have not been able to provide the health services expected by the community. Health costs are getting more expensive, but the quality of the services provided is a lot of complaints from the community.

Various policies have been taken by the government to help the community to reduce their burden of life. Health policy aims to facilitate/relieve people in accessing health services. The government has always tried to ease the burden on the community in the health sector, various policies have been taken for basic and referral health services. With this health service, it is hoped that the public's health status can increase and indirectly can also improve the quality and productivity of Indonesia's human resources (HR).

Approach to measuring welfare according to the United Nations Development Program (UNDP), the measurement of the level of welfare of the people/community is carried out based on the calculation of the Human Development Index (HDI) or HDI. This 
Jurnal Cahaya Mandalika, Vol. 2, No. 2, Juli 2021 ,e- ISSN: 2721-4796

Available online at: ojs.cahayamandalika.com/index.php/jcm

Copyright (c) 2021 Published by: Institut Penelitian \& Pengembangan Mandalika Indonesia

index is formed by 3 (three) basic dimensions, namely: health, knowledge, and a decent standard of living. The health dimension (health index) is measured by Life Expectancy at Birth $(\mathrm{AHH})$, which is defined as the average number of years a person can travel from birth. Community welfare has an effect on sustainable health development.

\section{CONCLUSION}

Based on the previous explanation, the following conclusions can be drawn.

1) Government policies have an effect on sustainable health development. Regulations made by the government are intended to support public health.

2) Social capital affects sustainable health development. To ensure the realization of sustainable health development, it is very dependent on social capital, especially the ability of the community to manage and overcome economic, social and environmental pressures.

3) Community welfare affects sustainable health development. A prosperous society is a society that has income that has costs for health purposes.

\section{REFERENCE}

Bradley JS, Byington CL, Shah SS, Alverson B, Carter ER, Harrison C. 2011. Executive summary: The management of community-acquired pneumonia in infants and children older than 3 months of age: Clinical practice guidelines by the Pediatric Infectious Diseases Society and the Infectious Diseases Society of America. Clin Inf Dis. 53(7):617-630.

Gunawan, Widodo, F.Y., \& Harijanto, T. 2015. Analisis Rendahnya Laporan Insiden Keselamatan Pasien di Rumah Sakit. Jurnal Kedokteran Brawijaya; 28(2): 206-213.

Haseltine, William A. 2013. Affordable Excellence: The Singapore Healthcare Story. Ridge Books, Singapore

IOM (Institute of Medicine). 2001. The Future of the Public's Health in the 21st Century. National Academy Press, Washington DC.

McKeon P. 2013. Coping with Depression and Elation. Arcan: Jakarta

Murti, B. 2013. Pengantar Ekonomi Kesehatan. Gadjah Mada University Press, Yogyakarta.

Notoatmodjo, S. 2003. Ilmu Kesehatan Masyarakat. Rineka Cipta: Jakarta.

Peraturan Menteri Kesehatan (Permenkes) Nomor 12 Tahun 2012 tentang Akreditasi Rumah Sakit.

Soeroo, Santoso. 2002. Manajemen Sumber Daya Manusia di Rumah Sakit. Jakarta, Penerbit EGC

Putnam R D. 1996. “The Prosperous Community : Social Capital and Public Life, The American of Prospect, Vol 13, pp 35-42

Lesser (2000), Knowledge and Social Capital: Foundation and Application,BostonBoutterwhorth-Heinneman

Fukuyama, Francis. 1995. Trust: Kebajikan Sosial dan Penciptaan Kemakmuran. Yogyakarta: Penerbit Qalam

Stiglitz Joseph E, Amartya Sen, Stiglitz Joseph E, Fitoussi Jean Paul, 2011. Mengukur Kesejateraan. Jakarta:Marjin Kiri.

Yustika, Ahmad Erani. 2012. Ekonomi Kelembagaan. Jakarta: Erlangga.

Mankiw, N.Gregory. 2007. Makroekonomi, Edisi Keenam. Jakarta : Erlangga

Bronstein, A.M., et al. 2009. Clinical disorder of balance, posture \& gait. New York: Oxford University Press 
Jurnal Cahaya Mandalika, Vol. 2, No. 2, Juli 2021 ,e- ISSN: 2721-4796

Available online at: ojs.cahayamandalika.com/index.php/jcm

Copyright ( 2021 Published by: Institut Penelitian \& Pengembangan Mandalika Indonesia

Sugiharto. Aris., 2007. Faktor-faktor Risiko Hipertensi Grade II pada Masyarakat. Universitas Diponegoro Semarang. Disertasi 